\title{
Optimalisasi Pengadaan Jumlah Produksi Barang Mengggunakan Metode Fuzzy Mamdani
}

\author{
Mohammad Badrul, Ayu Asari Sofia Romadona \\ STMIK Nusa Mandiri \\ Jl. Damai No. 8 Warung Jati Barat (Margasatwa) Jakarta Selatan \\ Telp. (021) 78839513 Fax. (021) 78839421 \\ mohammad.mbl@nusamandiri.ac.id, ayuasari09@gmail.com
}

\begin{abstract}
The challenges in the industrial world faced by companies are increasingly competitive, both service companies, trade and manufacturing. In terms of operational management, one of them, companies must improve the effectiveness and efficiency of company operations through modern operational methods and models such as production planning, production management and improvement, and so on. PT. Surya Pelangi Nusantara Sejahtera is engaged in manufacturing plastic products with the brand name GreenLeaf. Warehouse or storage area of goods has undergone a full warehouse and resulted in the boxes as containers of goods so that the goods can be easily damaged and the quality of goods that cannot be maintained thus causing a large influence on the financial sector. That was caused by the result of production entering the warehouse was not balanced with the expenditure of goods, causing a full warehouse to resolve the decision carried out using the Fuzzy Mamdani method. Optimization of the number of goods procurement is done by using three variables, namely sales, inventory and procurement. the result is that the Mamdani fuzzy method is accurate enough to determine the optimization of the amount of goods produced.
\end{abstract}

Keywords: Procurement, Production, Fuzzy Mamdani, Optimization

\section{Abstrak}

Tantangan di dunia industri yang dihadapi oleh perusahan semakin kompetitif, Baik perusahaan jasa, dagang maupun manufaktur. Dari segi manajemen operasional salah satunya, perusahaan harus meningkatkan efektifitas dan efisiensi operasional perusahaan melalui metode dan model operasional modern seperti perencanaan produksi, peningkatan dan manajemen produksi, dan sebagainya. PT. Surya Pelangi Nusantara Sejahtera bergerak dibidang pembuatan produk plastic yang bermerk GreenLeaf. Gudang atau tempat penyimpanan barang telah mengalami full warehouse dan mengakibatkan kardus-kardus sebagai media wadah barang jadi mudah rusak dan kualitas barang yang tidak bisa dipertahankan sehingga menyebabkan pengaruh besar pada sektor finansial. Hal itu disebabkan karena hasil produksi yang masuk ke gudang tidak seimbang dengan pengeluaran barang sehingga menyebabkan full warehouse. untuk menyelesaikan keputusan tersebut dilakukan dengan menggunakan metode Fuzzy Mamdani. Optimasi jumlah pengadaan barang dilakukan dengan menggunakan tiga variabel, yaitu penjualan, persediaan dan pengadaan. hasilnya metode fuzzy Mamdani cukup akurat untuk menentukan optimasi jumlah produksi barang.

Kata kunci: Pengadaan, Produksi, Fuzzy Mamdani, Optimalisasi

\section{PENDAHULUAN}

Tantangan di dunia industri yang dihadapi oleh perusahan semakin kompetitif, Baik perusahaan jasa, dagang maupun manufaktur. Salah satu slogan yang sedang hangat dibicarakan adalah industri 4.0. Industri 4.0 
adalah tren otomatisasi dan pertukaran data dalam teknologi manufaktur. Ini termasuk sistem cyber-physical, internet of things (IoT), komputasi awan, dan komputasi kognitif (Redaksi WE Online, 2019). Dari segi manajemen operasional salah satunya, perusahaan harus meningkatkan efektifitas dan efisiensi operasional perusahaan melalui metode dan model operasional modern seperti perencanaan produksi, peningkatan dan manajemen produksi, dan sebagainya (Marbun, Sihotang, \& Marbun, 2016). Hal ini mengharuskan perusahaan untuk merencanakan atau menentukan jumlah produksi, agar dapat memenuhi permintaan pasar dengan tepat waktu, juga dalam jumlah yang sesuai, sehingga diharapkan keuntungan perusahaan akan meningkat (Kusuma, Puspitasari, \& Gustiyo, 2018).

PT. Surya Pelangi Nusantara Sejahtera bergerak dibidang pembuatan produk plastic yang bermerk GreenLeaf. GreenLeaf memproduksi berbagai macam produk plastik dengan total 1000 lebih item yang terdiri dari peralatan rumah tangga, berkebun, industri dan furnitur. GreenLeaf mendistribusikan produk mereka ke seluruh Indonesia dan dunia. Gudang atau tempat penyimpanan barang jadi pada PT. Surya Pelangi Nusantara Sejahtera telah mengalami full warehouse dan mengakibatkan kardus-kardus sebagai media wadah barang jadi mudah rusak dan kualitas barang yang tidak bisa dipertahankan sehingga menyebabkan pengaruh besar pada sektor finansial. Hal itu disebabkan karena hasil produksi yang masuk ke gudang tidak seimbang dengan pengeluaran barang sehingga menyebabkan full warehouse. ketidakstabilan permintaan pasar terhadap produksi yang terkadang tinggi dan rendah, Untuk menyelesaikan permasalahan tersebut perlu diselesaikan dengan merencanakan jumlah produksi berdasarkan jumlah persediaan dan jumlah permintaan (Marbun, Sihotang, \& Marbun, 2016). Salah satu strategi tersebut adalah dengan perancanaan dan pengendalian produksi yang optimal dan matang. Perencanaan dan pengendalian produksi dapat diartikan sebagai aktivitas merencanakan serta mengendalikan material masuk dalam sistem produksi mengalir dalam sistem produksi, dan keluar dari sistem produksi sehingga permintaan dapat dipenuhi dengan efektif dan efisien (Eunike, Setyanto, Yuniarti, Hamdala, Lukodono, \& Fanani, 2018). Pada perusahaan optimasi produksi barang akan memberikan pengaruh besar, karena selain untuk pengotimalan bahan baku yang digunakan, hal ini juga akan berpengaruh besar pada sektor biaya akan finansial. Optimasi produksi barang pada perusahaan berpengaruh pada sektor finansial karena dapat memperkirakan pembelajaran bahan baku (Priyo, 2017), selain itu juga dalam hal biaya produksi maupun biaya transportasi dan penyimpanan. Oleh karena itu, perusahaan harus memperhitungkan tingkat persediaan serta perkiraan penjualan produk. Bila terdapat ketidaktepatan dalam menentukan jumlah produksi, maka akan mengakibatkan kelebihan jumlah produksi, sehingga menimbulkan persediaan yang menumpuk. Sebaliknya kekurangan produksi akan mengakibatkan kemacetan dalam proses penjualan, sehingga keuntungan yang bisa diperoleh perusahaan akan berkurang. Kondisi seperti ini bisa 
melancarkan operasi perusahaan dalam jumlah, waktu, mutu yang tepat serta biaya yang serendah-rendahnya sehingga bisa memaksimalkan laba/keuntungan perusahaan (Abrori \& Pimahayu, 2015).

Ada beberapa penelitian yang sudah dilakukan oleh beberapa peneliti yang membahas tentang optimalisasi pengadaan jumlah produksi barang seperti yang sudah dilakukan oleh (Ula, 2014) menjelaskan bahwa Optimasi jumlah pengadaan barang dilakukan dengan menggunakan tiga variabel, yaitu penjualan, persediaan dan pengadaan. Variabel penjualan terdiri dari dua himpunan fuzzy yaitu: turun dan naik, variabel persediaan terdiri dari dua himpunan fuzzy yaitu: sedikit dan banyak, sedangkan variabel pengadaan terdiri dari dua himpunan fuzzy, yaitu berkurang dan bertambah. Begitupula penelitian yang dilakukan oleh (Priyo, 2017) menyimpulkan bahwa, "Metode Mamdani lebih relevan dan tidak terlalu rumit untuk diterapkan pada permasalahan optimasi barang". Logika Fuzzy merupakan salah satu ilmu yang dapat menganalisa ketidakpastian. Banyaknya faktor yang terlibat dalam perhitungan menjadi kendala pembuat keputusan dalam mengambil kebijakan menentukan jumlah barang yang akan diproduksi. Beberapa dari faktor-faktor tersebut diantaranya adalah permintaan maksimum dan minimum dalam periode tertentu, permintaan saat ini, serta persediaan saat ini.

\section{METODOLOGI PENELITIAN}

\subsection{Tahapan Penelitian}

Berikut tahapan penelitian yang dilakukan untuk mengoptimalisasi pengadaan jumlah produksi barang menggunakan metode fuzzy mamdani.

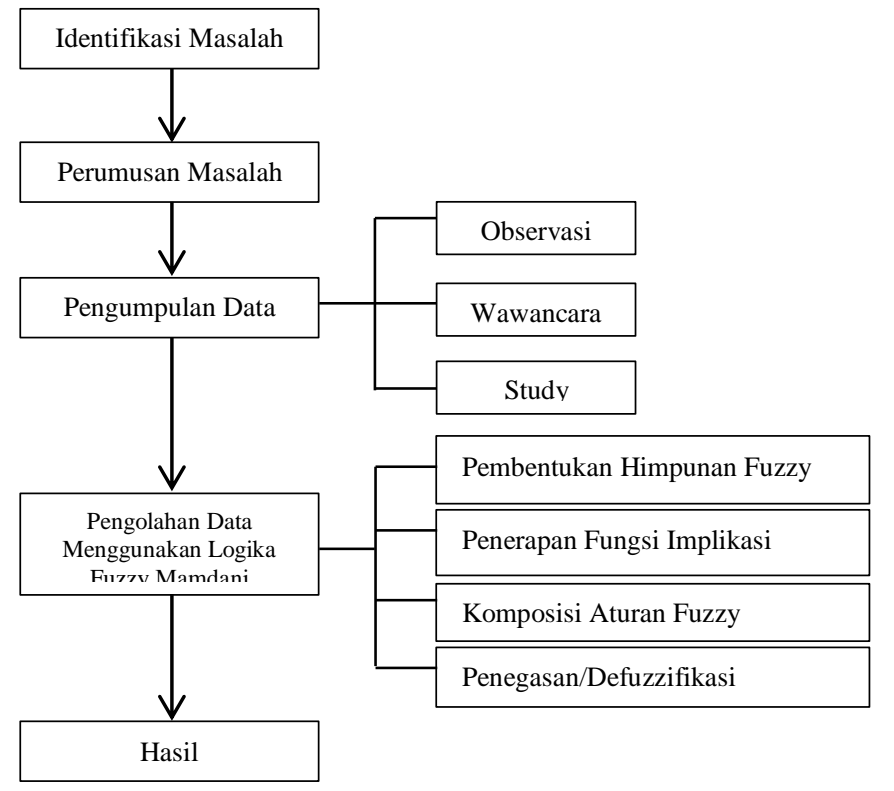

Gambar 1. Tahapan Penelitian 
Indentifikasi masalah dilakukan karena adanya permasalahan pada saat melakukan pengadaan jumlah produksi barang yang dianggap kurang akurat, sehingga dilakukan perumusan masalah dengan mengkaji penelitian terdahulu dan studi literatur dari berbagai referensi seperti buku dan jurnal dan referensi lain yang mendukung penelitian ini, selanjutnya dilakukan observasi dan wawancara untuk mengumpulkan data yang dibutuhkan, direkap, dan dilakukan penghitungan menggunakan metode Fuzzy Mamdani untuk melakukan pengadaan jumlah produksi barang kemudian menjabarkan hasil penelitian yang dilakukan dengan membuat kesimpulan serta saran.

\subsection{Logika Fuzzy}

Logika fuzzy dikatakan sebagai logika baru yang lama, sebab ilmu tentang logika fuzzy modern dan metodis baru ditemukan beberapa tahun yang lalu padahal sebenarnya konsep tentang logika fuzzy itu sendiri sudah ada sejak lama.Penjelasan mengenai ketiga metode tersebut sebagai berikut (Priyo, 2017):

a. Metode Mamdani (Min-Max)

Untuk metode ini, pada setiap aturan yang berbentuk implikasi ("sebab-akibat") antesenden yang berbentuk konjungsi (AND) mempunyai nilai keanggotaan berbentuk minimum (min), sedangkan maksimum (max), karena himpunan aturan-aturannya bersifat independen (tidak saling bergantungan).

b. Metode Tsukamoto

Pada metode Tsukamoto, setiap aturan direpresentasikan menggunakan himpunan-himpunan fuzzy, dengan fungsi keanggotaan yang monoton. Untuk menentukan nilai asli yang tegas (output crisp/crisp solution) dicari dengan cara mengubah input (berupa himpunan fuzzy yang diperoleh dari komposisi aturan-aturan fuzzy) menjadi suatu bilangan pada domain himpunan fuzzy tersebut. Cara ini disebut dengan defuzzifikasi (penegasan). Metode dengan defuzzifikasi dalam metode ini menggunakan rata-rata terpusat (Center Average Defuzzyfier).

c. Metode Takagi-Sugeno

Metode Takagi-Sugeno adalah metode dengan mengasumsikan suatu sistem dengan $m$ input yaitu $x_{1}, x_{2} \ldots, x n$ dan satu output yaitu dan satu output yaitu Y. Pada dasarnya model fuzzy dari sistem ini terdiri atas basis aturan dengan $n$ aturan penarikan kesimpulan fuzzy.

\section{HASIL DAN PEMBAHASAN}

\subsection{Metode Analisa Data}

Untuk mencapai tujuan penelitian maka analisis yang digunakan adalah data kuantitatif. Analisa data kuantitatif merupakan suatu analisa data yang 
digunakan apabila kesimpulan-kesimpulan yang diperoleh dapat dibuktikan dengan angka-angka dan juga dalam perhitungan dipergunakan namun yang ada hubungan dengan analisa penulisan. Data yang akan digunakan untuk analisa data adalah data historis persediaan, jumlah permintaan, dan hasil produksi periode Mei 2018 s/d Juni 2019 dalam kurun waktu 1 tahun sesuai dengan konsep sampling dari populasi yang ada. Berikut Penulis sajikan data yang akan dianalisa untuk tahap berikutnya.

Tabel 1. Rekapitulasi Data Permintaan, Persediaan, dan Jumlah Produksi Mei 2018 - Juni 2019

\begin{tabular}{|c|c|c|c|c|}
\hline No. & Bulan/Tahun & Permintaan (Dus) & Persediaan (Dus) & Produksi (Dus) \\
\hline 1 & Mei 2018 & 532 & 10 & 550 \\
\hline 2 & Juni 2018 & 206 & 18 & 220 \\
\hline 3 & Juli 2018 & 518 & 5 & 530 \\
\hline 4 & Agustus 2018 & 565 & 6 & 580 \\
\hline 5 & September 2018 & 685 & 8 & 700 \\
\hline 6 & Oktober 2018 & 686 & 6 & 700 \\
\hline 7 & November 2018 & 632 & 5 & 650 \\
\hline 8 & Desember 2018 & 443 & 7 & 460 \\
\hline 9 & Januari 2019 & 497 & 16 & 510 \\
\hline 10 & Februari 2019 & 362 & 8 & 380 \\
\hline 11 & Maret 2019 & 536 & 9 & 550 \\
\hline 12 & April 2019 & 484 & 12 & 500 \\
\hline 13 & Mei 2019 & 522 & 7 & 550 \\
\hline 14 & Juni 2019 & 417 & 8 & 430 \\
\hline
\end{tabular}

Sumber : Bagian Operasional PT. Surya Pelangi Nusantara Sejahtera

Metode Mamdani paling sering digunakan dalam aplikasi - aplikasi karena strukturnya yang sederhana, yaitu menggunakan operasi $M I N-M A X$ atau MAX-PRODUCT. Untuk mendapatkan output, diperlukan empat tahapan berikut :

1) Pembentukan Himpunan Fuzzy/ Fuzzifikasi yaitu menentukan semua variabel yang terkait dalam proses yang akan ditentukan. Untuk masingmasing variabel input, tentukan suatu fungsi fuzzifikasi yang sesuai. Pada metode Mamdani, baik variabel input maupun variabel output dibagi menjadi satu atau lebih himpunan fuzzy. Untuk menentukan variable tersebut penulis menggunakan fungsi derajat keanggotaan Representasi Linear. Ada beberapa hal yang perlu diketahui dalam memahami sistem fuzzy, yaitu:

a. Variable Fuzzy

Variable fuzzy merupakan variable yang hendak dibahas dalam suatu system fuzzy antara lain: jumlah permintaan, persediaan, dan produksi.

b. Himpunan Fuzzy

Himpunan fuzzy merupakan suatu grup yang mewakili suatu kondisi atau keadaan tertentu dalam suatu variable fuzzy, sebagai berikut:

1) Variabel Permintaan terbagi menjadi 3 himpunan fuzzy, yaitu : RENDAH dan TINGGI. 
2) Variabel Persediaan terbagi menjadi 3 himpunan fuzzy, yaitu : SEDIKIT dan BANYAK.

3) Variabel Produksi terbagi menjadi 3 himpunan fuzzy, yaitu : BERKURANG dan BERTAMBAH.

Berikut grafik untuk perhitungan fungsi derajat keanggotaan Representasi Linear :

a) Linear Naik

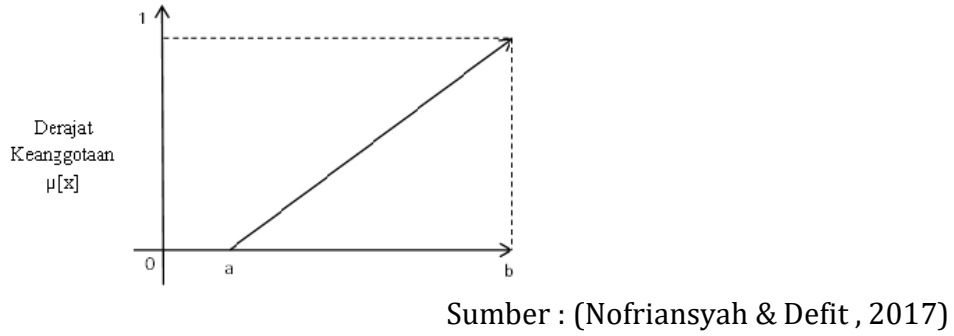

Gambar 2. Representasi Linear Naik

$$
\mu[x, \alpha, b]=\left\{\begin{array}{cc}
0 ; & x \leq a \\
(x-a) /(b-a) ; & a \leq x \leq b \\
1 ; & x \geq b
\end{array}\right.
$$

Rumus Representasi Linear Naik

Keterangan :

$\mathrm{a}=$ nilai domain yang mempunyai derajat keanggotaan nol

$\mathrm{b}=$ nilai domain yang mempunya derajat keanggotaan satu

$\mathrm{x}=$ nilai input yang akan di ubah ke dalam bilangan fuzzy

b) Linear Turun

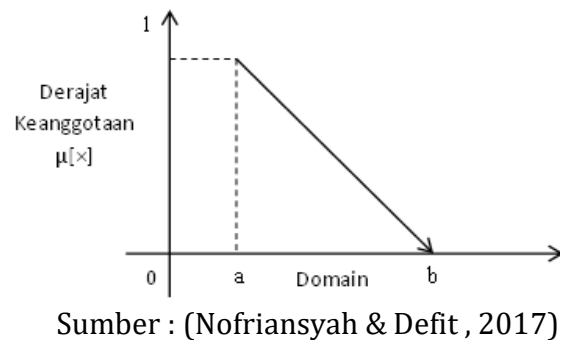

Gambar 3. Representasi Linear Turun

$$
\mu[x, \alpha, b]=\left\{\begin{array}{cc}
(b-x) /(b-a) ; & a \leq x \leq b \\
0 ; & x \geq b
\end{array}\right.
$$

Rumus Representasi Linear Naik

Keterangan :

$\mathrm{a}=$ nilai domain yang mempunyai derajat keanggotaan satu

$\mathrm{b}=$ nilai domain yang mempunya derajat keanggotaan nol

$\mathrm{x}=$ nilai input yang akan di ubah ke dalam bilangan fuzzy.

c) Semesta Pembicaraan

Semesta pembicaraan adalah keseluruhan nlai yang diperbolehkan untuk dioperasikan dalam suatu variable fuzzy. Semesta pembicaran 
merupakan himpunan bilangan real yang senantiasa naik (bertambah) secara monoton dari kiri ke kanan. Berikut ini hasil perhitungan nilai semesta pembicaraan dan domain himpunan fuzzy menggunakan fungsi derajat keanggotaan Representasi Linear:

Tabel 2. Nilai Semesta Pembicaraan Dan Domain Himpunan Fuzzy

\begin{tabular}{|c|c|c|c|l|c|}
\hline No. & Fungsi & $\begin{array}{c}\text { Nama } \\
\text { Variabel }\end{array}$ & $\begin{array}{c}\text { Semesta } \\
\text { Pembicaraan }\end{array}$ & $\begin{array}{l}\text { Nama Himpunan } \\
\text { Fuzzy }\end{array}$ & Domain \\
\hline 1 & \multirow{2}{*}{ Input } & Permintaan & {$[0,+\infty]$} & Rendah & {$[0,686]$} \\
\cline { 4 - 6 } & & & Tinggi & {$[206,+\infty]$} \\
\cline { 4 - 6 } & & Persediaan & {$[0,+\infty]$} & Sedikit & {$[0,18]$} \\
\cline { 4 - 6 } & & & Banyak & {$[5,+\infty]$} \\
\hline 2 & \multirow{2}{*}{ Output } & Produksi & {$[0,+\infty]$} & Berkurang & {$[0,700]$} \\
\cline { 4 - 6 } & & & Bertambah & {$[220,+\infty]$} \\
\hline
\end{tabular}

1. Penerapan Fungsi Implikasi menggunakan aturan MIN. MIN (minimum).

Fungsi ini akan memotong output himpunan fuzzy.

2. Komposisi Aturan Fuzzy menggunakan metode MAX (menghasilkan himpunan fuzzy baru). Metode MAX (Maximum) pada metode ini, solusi himpunan fuzzy diperoleh dengan cara mengambil nilai maksimum aturan, kemudian menggunakannya untuk memodifikasi daerah fuzzy, dan mengaplikasikannya ke output dengan menggunakan operator OR (union). Jika semua proposisi telah di evaluasi, maka output akan berisi suatu himpunan fuzzy yang merefleksikan konstribusi dari tiap-tiap proposisi. Secara umum dapat dituliskan :

$\mu_{s f}\left[x_{i}\right]=\max \left(\mu_{s f}\left[x_{i}\right], \mu_{k f}\left[x_{i}\right]\right)$

Dengan:

$\mu_{s f}\left[x_{i}\right]=$ nilai keanggotaan solusi fuzzy sampai aturan ke-i;

$\mu_{k f}\left[x_{i}\right]=$ nilai keanggotaan konsekuen fuzzy aturan ke-I;

3. Defuzzyfikasi menggunakan metode Centroid (Composite Moment). Pada metode ini, solusi crisp diperoleh dengan cara mengambil titik pusat $\left(z^{*}\right)$ daerah fuzzy. Secara umum dirumuskan :

$Z^{*}=\frac{\int_{a}^{b} z \mu(z) d z}{\int_{a}^{b} \mu(z) d z}$

Untuk variabel kontinu, dengan $z^{*}$ adalah nilai hasil defuzzifikasi dan $\mu[z]$ adalah derajat keanggotaan titik tersebut, sedangkan adalah nilai domain ke-i.

\subsection{Analisa dengan Metode Fuzzy Mamdani}

Terdapat beberapa langkah untuk melakukan perhitungan penentuan jumlah produksi menggunakan logika fuzzy metode Mamdani : 


\subsubsection{Pembentukan Himpunan Fuzzy/ Fuzzifikasi}

Pada tahap ini, nilai keanggotaan himpunan permintaan dan persediaan saat ini dicari menggunakan fungsi keanggotaan himpunan fuzzy dengan memperhatikan data hasil wawancara. Berikut ini tabel data untuk mendefinisikan Variabel Fuzzy:

Tabel 3. Definisi Variabel Fuzzy

\begin{tabular}{|c|c|c|}
\hline \multicolumn{2}{|c|}{ Variabel } & \multirow{2}{*}{ Satuan } \\
\cline { 1 - 2 } Linguistik & Numerik & \\
\hline PmtRendah & 206 & Dus/Bulan \\
\hline PmtTinggi & 686 & Dus/Bulan \\
\hline PsdSedikit & 5 & Dus/Bulan \\
\hline PsdBanyak & 18 & Dus/Bulan \\
\hline ProBerkurang & 220 & Dus/Bulan \\
\hline ProBertambah & 700 & Dus/Bulan \\
\hline
\end{tabular}

Sumber : Hasil Penelitian

Perhitungan yang telah dilakukan menggunakan fungsi derajat keanggotaan Representasi Linear, sebagai berikut :

\section{a) Fuzzifikasi Variabel Permintaan}

Berdasarkan data permintaan $(x)$ paling tinggi yaitu 686 dus dan paling rendah yaitu 206 dus, maka fungsi keanggotaan dirumuskan sebagai berikut :

$$
\begin{gathered}
\mu_{\text {PITEENDAH }}=\left\{\begin{array}{cc}
(686-x) /(686-206) ; & 206 \leq x \leq 686 \\
0 ; & x \geq 686 \\
0 ; & x \leq 206
\end{array}\right. \\
\mu_{\text {PmtTINGGI }}=\left\{\begin{array}{cc}
(x-206) /(686-206) ; & 206 \leq x \leq 686 \\
1 ; & x \geq 686
\end{array}\right.
\end{gathered}
$$

Jika diketahui permintaan sebanyak 417 dus, maka :

$$
\begin{aligned}
& \mu_{\text {PITEENDAH }}(417)=\frac{686-417}{686-206}=\frac{269}{480}=0,560 \\
& \mu_{\text {PmtTINGGI }}(417)=\frac{417-206}{686-206}=\frac{211}{480}=0,439
\end{aligned}
$$

Grafik Linear Permintaan Rendah

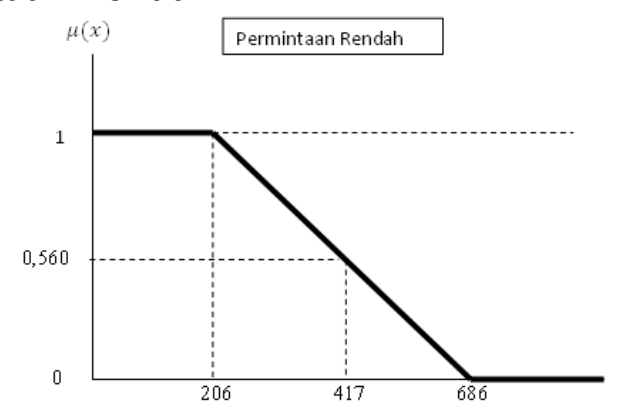

Gambar 4. Grafik Permintaan Rendah 
Grafik Linear Permintaan Tinggi

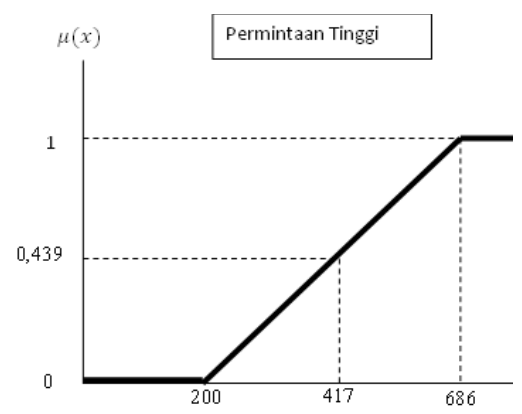

Gambar 5. Grafik Permintaan Tinggi

\section{b) Fuzzifikasi Variabel Persediaan}

Berdasarkan data persediaan $(y)$ paling banyak yaitu 18 dus dan paling sedikit 5 dus, maka fungsi keanggotaan dirumuskan sebagai berikut :

$$
\begin{gathered}
\mu_{\text {PSISEDIKIT }}=\left\{\begin{array}{cc}
(18-x) /(18-5) ; & 5 \leq x \leq 18 \\
0 ; & x \geq 18
\end{array}\right. \\
\mu_{\text {PIItBANYAK }}=\left\{\begin{array}{cc}
(x-5) /(18-5) ; & 5 \leq x \leq 18 \\
1 ; & x \geq 18
\end{array}\right.
\end{gathered}
$$

Jika diketahui persediaan sebanyak 5 , maka :

$$
\begin{gathered}
\mu_{P S d S E D I K I T}(8)=\frac{18-8}{18-5}=\frac{10}{13}=0,769 \\
\mu_{P S d B A N Y A K}(8)=\frac{8-5}{18-5}=\frac{3}{13}=0,230
\end{gathered}
$$

Grafik Persediaan Sedikit

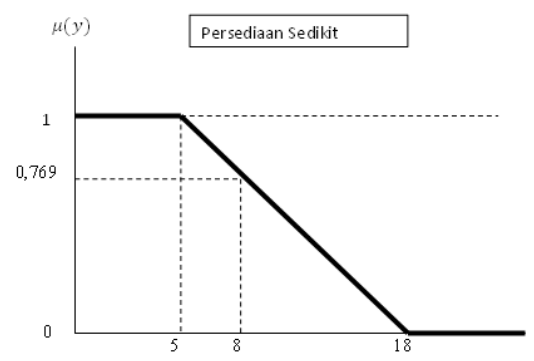

Gambar 6. Grafik Persediaan Sedikit 
Grafik Persediaan Banyak

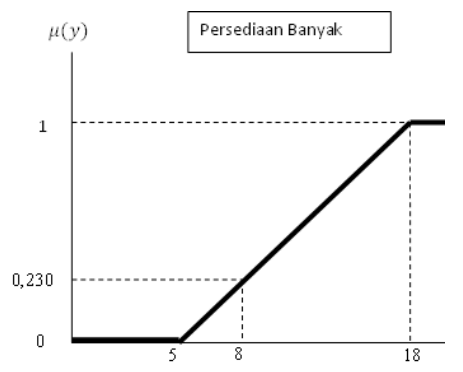

Sumber : Hasil Penelitian

Gambar 7. Grafik Persediaan Banyak

\section{c) Fuzzifikasi Variabel Produksi}

Berdasarkan data produksi (z) paling banyak yaitu 700 dus dan paling sedikit 220 dus, maka fungsi keanggotaan dirumuskan sebagai berikut dan grafik fungsi keanggotaan disajikan sebagai berikut :

$$
\begin{aligned}
& \mu_{\text {PSdBERKURANG }}=\left\{\begin{array}{cc}
(700-x) /(700-220) ; & 220 \leq x \leq 700 \\
0 ; & x \geq 700 \\
0 ; & x \leq 220
\end{array}\right. \\
& \mu_{\text {PITBERTAMBAH }}=\left\{\begin{array}{cc}
0 ; & x \leq 220 \\
(x-220) /(700-220) ; & 700 \leq x \leq 220 \\
1 ; & x \geq 700
\end{array}\right.
\end{aligned}
$$

Grafik Produksi Berkurang

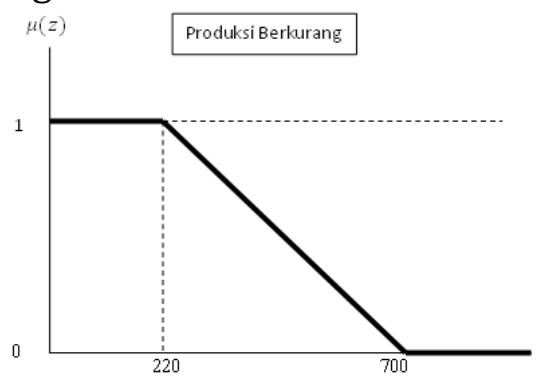

Gambar 8. Grafik Produksi Berkurang

Grafik Produksi Bertambah

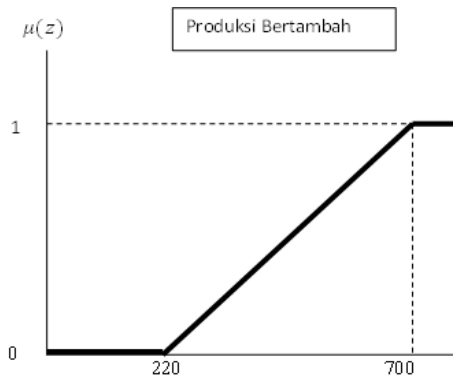

Sumber : Hasil Penelitian

Gambar 9. Grafik Produksi Bertambah 


\subsubsection{Penerapan Fungsi Implikasi Aturan MIN}

Pembentukan Aturan Fuzzy dari dua variable input dan sebuah variable output yang telah didefinisikan, dengan melakukan analisa data terhadap batas tiap - tiap himpunan fuzzy pada tiap - tiap variabelnya maka terdapat 4 aturan fuzzy yang akan dipakai dalam system ini, maka kombinasi aturanaturan implikasi fuzzy yang berlaku sebagai berikut :

Tabel 4. Kombinasi Aturan-aturan Implikasi Fuzzy yang Berlaku

\begin{tabular}{|c|c|c|c|c|}
\hline Aturan & PMT & PSD & Fungsi Implikasi & Produksi \\
\hline R1 & Rendah & Banyak & $\Rightarrow$ & Berkurang \\
\hline R2 & Rendah & Sedikit & $\Rightarrow$ & Berkurang \\
\hline R3 & Tinggi & Banyak & $\Rightarrow$ & Bertambah \\
\hline R4 & Tinggi & Sedikit & $\Rightarrow$ & Bertambah \\
\hline
\end{tabular}

Sumber : Hasil Penelitian

Penjelasan mesin inferensi dengan susunan aturan $I F$ Permintaan $A N D$ Persediaan THAN Produksi, hasilnya yaitu :

[R1] IF Permintaan RENDAH AND Persediaan BANYAK THEN Produksi BERKURANG

$a-$ predikat $_{1}=\mu_{\text {pmt }} R E N D A H[x] \cap \mu_{p s d} B A N Y A K[y]$

$=\min (0,560 ; 0,230)=0,230$

[R2] IF Permintaan RENDAH AND Persediaan SEDIKIT THEN Produksi BERKURANG

$a-$ predikat $_{2}=\mu_{\text {pmt }} R E N D A H[x] \cap \mu_{p s d} \operatorname{SEDIKIT}[y]$

$=\min (0,560 ; 0,769)=0,560$

[R3] IF Permintaan TINGGI AND Persediaan BANYAK THEN Produksi BERTAMBAH

$a$ - predikat $_{3}=\mu_{\text {pmt }}$ TINGGI $[x] \cap \mu_{p s d}$ BANYAK $[y]$

$=\min (0,439 ; 0,230)=0,230$

[R4] IF Permintaan TINGGI AND Persediaan SEDIKIT THEN Produksi BERTAMBAH

$a-$ predikat $_{4}=\mu_{\text {pmt }}$ TINGGI $[x] \cap \mu_{p s d} \operatorname{SEDIKIT}[y]$

$=\min (0,439 ; 0,769)=0,439$

\subsubsection{Komposisi Aturan Fuzzy Metode MAX}

Komposisi aturan pada penelitian ini menggunakan metode Max (maximum) yaitu dengan cara mengambil nilai maksimum dari semua aturan, maka :

$$
\begin{aligned}
& \frac{a_{1}-220}{700-220}=0,230 \\
& a_{1}=0,230(700-220)+220 \\
& a_{1}=330,4
\end{aligned}
$$




$$
\begin{aligned}
& \frac{a_{2}-220}{700-220}=0, \\
& a_{2}=0,560(700-220)+220 \\
& a_{2}=488,8
\end{aligned}
$$

$$
\mu_{\text {Produksi }}[z]=\left\{\begin{array}{c}
0,230 ; z \leq 330,4 \\
\frac{z-220}{480} ; 330,4 \leq z \leq 488,8 \\
0,560 ; z \geq 488,8
\end{array}\right.
$$

Gabungan (Union) himpunan - himpunan fuzzy konsekuen semua aturan yang berlaku (atau maksimum dari semua derajat keanggotaan konsekuen semua aturan) sebagai berikut :

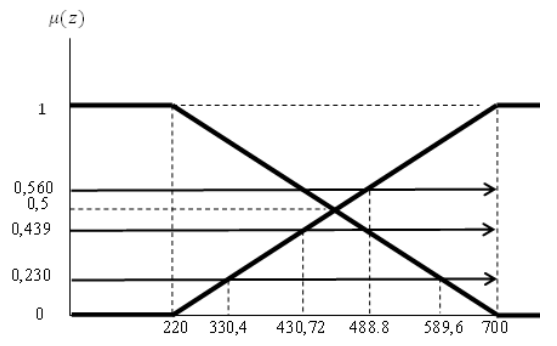

Gambar 10. Grafik Kompoisi Aturan (gabungan)

Sumber : Hasil Penelitian

\subsubsection{Penegasan/ Defuzzifikasi Metode Centroid}

Pada penelitian yang menggunakan metode Mamdani, proses defuzzifikasi dilakukan menggunakan metode Centroid. Karena domain kontinu, maka rumus yang berlaku adalah :

$$
Z^{*}=\frac{\int_{a}^{b} z \mu(z) d z}{\int_{a}^{b} \mu(z) d z}=\frac{M_{1}+M_{2}+M_{3}}{A_{1}+A_{2}+A_{3}}
$$

Untuk menghitung Momen $(M)$ dan Luasan daerah $(A)$ dari gabungan komposisi pada langkah sebelumnya, maka grafik komposisi aturan dapat dipetakan sebagai berikut:

Selanjutnya, dapat dihitung nilai Momen dan Luasan dari masing-masing daerah sesuai pada grafik diatas, sebagai berikut :

Momen $\left(M_{1}\right)$ :

$$
\begin{aligned}
& \int_{0}^{330,4} z \mu(z) d z=\int_{0}^{330,4} 0,230(z) d z=12.553,8784 \\
& \int_{330,4}^{488,8} z \mu(z) d z=\int_{330,4}^{488,8} \frac{z-220}{700-220}(z) d z=26.317,839608 \\
& \text { Momen }\left(M_{3}\right): \\
& \int_{488,8}^{700} z \mu(z) d z=\int_{488.8}^{700} 0,560(z) d z=70.300,8768 \\
& \quad \text { Luas }\left(A_{1}\right)=0,230 \times 330,4=75,992 \\
& \quad \text { Luas }\left(A_{2}\right)=(0,230+0,560) \cdot \frac{(488,8-330,4)}{2}=62,568 \\
& \quad \text { Luas }\left(A_{3}\right)=0,560(700-489)=118,272
\end{aligned}
$$


Maka,

$$
Z^{*}=\frac{M_{1}+M_{2}+M_{3}}{A_{1}+A_{2}+A_{3}}=\frac{109.172,59481}{256,832}=425,07395811
$$

\section{SIMPULAN}

Dari hasil perhitungan diatas bahwa hipotesis menunjukan terdapat perbedaan nilai hasil produksi sebelum dan sesudah memakai perhitungan metode Mamdani. Hasil perhitungan relatif sama dengan hasil perhitungan menggunakan Microsoft Excel yaitu sebesar 425. Perbedaan tersebut dikarenakan pada Microsoft Excel terjadi beberapa pembulatan, sehingga output yang dihasilkan sedikit berbeda.

Tabel 5. Perbandingan Hasil Produksi Perusahaan dan Metode Mamdani

\begin{tabular}{|c|c|c|c|c|c|}
\hline \multirow{2}{*}{ No } & \multirow{2}{*}{ Bulan/Tahun } & \multicolumn{2}{|c|}{ Input } & \multicolumn{2}{c|}{ Output (Produksi } \\
\cline { 3 - 5 } & & PMT & PSD & PRO & Mamdani \\
\hline 1 & Mei 2018 & 532 & 10 & 550 & 404.9573618 \\
\hline 2 & Juni 2018 & 206 & 18 & 220 & 540 \\
\hline 3 & Juli 2018 & 518 & 5 & 530 & 525.4814815 \\
\hline 4 & Agustus 2018 & 565 & 6 & 580 & 500.7600503 \\
\hline 5 & September 2018 & 685 & 8 & 700 & 532.223807 \\
\hline 6 & Oktober 2018 & 686 & 6 & 700 & 539.1208791 \\
\hline 7 & November 2018 & 632 & 5 & 650 & 538.1797753 \\
\hline 8 & Desember 2018 & 443 & 7 & 460 & 445.1158687 \\
\hline 9 & Januari 2019 & 497 & 16 & 510 & 458.1194084 \\
\hline 10 & Februari 2019 & 362 & 8 & 380 & 438.682373 \\
\hline 11 & Maret 2019 & 536 & 9 & 550 & 416.7391571 \\
\hline 12 & April 2019 & 484 & 12 & 500 & 370.3672628 \\
\hline 13 & Mei 2019 & 522 & 7 & 550 & 463.7292255 \\
\hline 14 & Juni 2019 & 417 & 8 & 430 & 424.8750277 \\
\hline
\end{tabular}

Sumber : Hasil Penelitian

Tabel 6. Perbandingan Hasil Produksi Perusahaan dan Metode Mamdani Setelah Dibulatkan seperti berikut

\begin{tabular}{|c|c|c|c|c|c|}
\hline \multirow{2}{*}{ No. } & Bulan/ Tahun & \multicolumn{2}{|c|}{ Input } & \multicolumn{2}{c|}{ Output (Produksi } \\
\cline { 3 - 6 } & & PMT & PSD & PRO & Mamdani \\
\hline 1 & Mei 2018 & 532 & 10 & 550 & 405 \\
\hline 2 & Juni 2018 & 206 & 18 & 220 & 540 \\
\hline 3 & Juli 2018 & 518 & 5 & 530 & 526 \\
\hline 4 & Agustus 2018 & 565 & 6 & 580 & 501 \\
\hline 5 & September 2018 & 685 & 8 & 700 & 533 \\
\hline 6 & Oktober 2018 & 686 & 6 & 700 & 540 \\
\hline 7 & November 2018 & 632 & 5 & 650 & 539 \\
\hline 8 & Desember 2018 & 443 & 7 & 460 & 446 \\
\hline 9 & Januari 2019 & 497 & 16 & 510 & 459 \\
\hline 10 & Februari 2019 & 362 & 8 & 380 & 439 \\
\hline 11 & Maret 2019 & 536 & 9 & 550 & 417 \\
\hline 12 & April 2019 & 484 & 12 & 500 & 371 \\
\hline 13 & Mei 2019 & 522 & 7 & 550 & 464 \\
\hline 14 & Juni 2019 & 417 & 8 & 430 & 425 \\
\hline
\end{tabular}

Sumber : Hasil Penelitian 


\section{DAFTAR PUSTAKA}

[1] Abrori, M., \& Pimahayu, A. H. (2015). Aplikasi Logika Fuzzy Metode Mamdani dalam Pengambilan Keputusan Penentuan Jumlah Produksi. Jurnal Kaunia, 91.

[2] Eunike, A., Setyanto, N. W., Yuniarti, R., Hamdala, I., Lukodono, R. P., \& Fanani, A. A. (2018). Perencanaan Produksi dan Pengendalian Persediaan. Malang: UB Press.

[3] Kusuma, A. P., Puspitasari, W. D., \& Gustiyo, T. (2018). Sistem Pendukung Keputusan dalam Menentukan Jumlah Produksi Seragam Menggunakan Metode Fuzzy Tsukamoto. Jurnal Antivirus, 1.

[4] Marbun, M., Sihotang, H. T., \& Marbun, N. V. (2016). Perancangan Sistem Perencanaan Jumlah Produksi Roti dengan Metode Fuzzy Mamdani. Jurnal Mantik Penusa, 48.

[5] Nofriansyah , D., \& Defit, S. (2017). Multi Criteria Decision Making (MCDM) pada Sistem Pendukung Keputusan. Yogyakarta: CV Budi Utama .

[6] Priyo, W. T. (2017). Penerapan Logika Fuzzy dalam Optimasi Produksi Barang Menggunakan Metode Mamdani. Jurnal Ilmiah Soulmath, 14.

[7] Redaksi WE Online. (2019, 7 5). Wartaekonomi. Retrieved 1 31, 2020, from https://www.wartaekonomi.co.id/: https://www.wartaekonomi.co.id/read235191/tantangan-dan-masa-depan indonesia-dalam-era-industri-40

[8] Ula, M. (2014). Implementasi Logika Fuzzy dalam Optimasi Pengadaan Barang Menggunakan Metode Tsukamoto. Jurnal Ecotipe, 36. 